DOI https://doi.org/10.30525/978-9934-26-184-8-6

\title{
ІДЕНТИФІКАЦІЯ ГЕНОТИПІВ І ФЕНОТИПІВ ОЗИМОЇ ПШЕНИЦІ М'ЯКОЇ ЗА ФОТОЧУТЛИВІСТЮ
}

\author{
Файт В. I. \\ доктор біологічних наук, \\ член-кореспондент \\ Національної академї аграрних наук України, \\ завідувач відділу загальної та молекулярної генетики \\ Селекційно-генетичний інститут - Національний центр \\ насіннсзнавства та сортовивчення

\section{Стельмах А. Ф.} \\ доктор біологічних наук, професор, \\ академік Національної академії аграрних наук України, \\ головний науковий співробітник відділу загальної \\ та молекулярної генетики \\ Селекиійно-генетичний інститут - Національний центр \\ насіннєзнавства та сортовивчення

\section{Балашова I. A.} \\ кандидат біологічних наук, \\ провідний науковий співробітник відділу загальної \\ та молекулярної генетики \\ Селекиійно-генетичний інститут - Національний цеентр \\ насіннєзнавства та сортовивчення \\ м. Одеса, Украӥна
}

Пшениця (Triticum aestivum L.) може вирощуватися в широкому діапазоні агроклиматичних регіонів. Одним 3 ключових факторі такої успішної широкої адаптації є мінливість строків цвітіння, що дозволяє уникнути негативних температур, теплового стресу або стресу від посухи [1, с. 2]. Час цвітіння пшениці, головним чином, визначається двома факторами навколишнього середовища: температурою і фотоперіодом, які $€$ 
основою для розподілу генотипів пшениці за типом розвитку на озимі або ярі (з потребою в яровизації або без такої) та нечутливі або чутливі до фотоперіоду [2, с. 306]. Чутливі до фотоперіоду сорти потребують тривалого дня для індукції цвітіння, оскільки умови скороченого дня подовжують вегетативну фазу i затримують перехід до репродуктивного розвитку. Нечутливі до фотоперіоду генотипи цвітуть незалежно від тривалості дня. Основними регуляторами фотоперіодичної відповіді у пшениці $є$ гени Ppd-1 (Ppd-A1, Ppd-B1 и Ppd-D1), розташовані на хромосомах другої групи 2A, 2B і 2D [3, с. 190]. Домінантні алелі генів Ppd-1 знижують чутливість рослин до тривалості дня, що призводить до більш раннього колосіння як в умовах скороченого так і подовженого дня.

Для сучасних сортів озимої пшениці України характерна слабка або середня чутливість до фотоперіоду що сприяє значному скороченню періоду до колосіння та суттєвому збільшенню урожаю в місцевих умовах та викликає виправдану занепокоєність стосовно суттєвого зниження потенціалу зимоморозостійкості такого роду генотипів [4, с. 262; 5, с. 119].

Протягом останніх сезонів ми здійснюємо молекулярногенетичну ідентифікацію $P p d$ генотипів широкого набору колекційних зразків озимої пшениці м'якої різного походження та фенотипову оцінку їхніх рівнів фоточутливості.

Маркерування алелів гена $P p d-D 1$ здійснювали за рекомендаціями Beales та інш. [6, с. 727], гена Ppd-B1 за методикою Chen та інш. [7, с. 9], запропонований Wilhelm та інш. [8, с. 287] ПЛРтест використано для ідентифікації алелів гена $P p d-A 1$. Оцінку рівнів фоточутливості досліджуваних зразків виконували за розробленою нами методикою вирощування на природному та скороченому фотоперіодах попередньо прояровизованих при температурі $+1{ }^{\circ} \mathrm{C} 5$-денних зелених проростків протягом не менш як 55 діб [9, с. 104].

Із застосуванням діагностичних молекулярних маркерів були ідентифіковані генотипи за генами Ppd-A1, Ppd-B1 i Ppd-D1 у 232 сортів озимої м’якої пшениці 3 різних країн, 1613 яких українські. Найбільш поширеним серед досліджених сортів виявився алель Ppd-Dla (81\%) - з варіюванням від 10\% у сортів 
США до 92 \% у сортів України. Частоти алелів Ppd-Bla і Ppd-Blc у загальній вибірці незначні - лише 3 і 5\% відповідно. Локус $P p d$ $A 1$ не виявив алельних варіацій, отже, всі 232 генотипи є носіями рецесивного алеля $P p d-A 1$.

Взагалі, у сортів виявлено шість різних Ppd-1 генотипів. У сортів більшості країн виявлено два (Росія) або три (країни Свропи, США, Україна) і лише в вибірці сортів Японії, яка була мало чисельною - чотири $P p d-1$ генотипи. 3 більшою частотою (75\%) виявлені домінантні тільки за алелем Ppd-Dla генотипи, 3 варіюванням від 10\% (США) до 89\% (Україна). Частоти всіх інших моногенно або дигенно домінантних генотипів-носіїв генів $P p d-1$, були досить низькі (від 1 до 4\%). Моногенно домінантний за Ppd-Bla генотип відмічений лише у трьох сортів США, а моногенно домінантний $P p d-B 1 c-$ у японського сорту Norin 1 та у лінії Triple Dirk C з Австралії. Генотип з комбінацією алелів PpdDla Ppd-Bla ідентифікований у трьох сортів Японії та у киргизького сорту Еритроспермум 80, а Ppd-Dla Ppd-Blc - у поодиноких сортів Італії, Сербіï, Японії і п’яти сортів України.

У цілому, серед сортів України і Росії порівняно з сортами країн Європи та США частка сортів-носіїв тільки домінантного алеля Ppd-Dla (слабко чутливі) виявилася достовірно вищою, що супроводжувалося паралельним зменшенням частки повністю рецесивних за трьома генами $P p d-1$ генотипів з проявою сильного рівня фоточутливості. Вітчизняні селекціонери в деякій мірі вважають цей факт як доказ більшої адаптованості домінантних генотипів до еколого-географічних умов регіону. 3 іншого ж боку, існує й думка, що сильна фоточутливість (як і тривала потреба в яровизації) можуть обмежувати досягнення селекційним шляхом підвищення потенціальної продуктивності для сучасних сортів озимих пшениць. I тому в більшості вони вже не включають у програми гібридизації фоточутливі донори.

Наскільки обгрунтовані таки погляди, спробуємо розібратися за результатами оцінок фенотипів щодо рівнів фоточутливості сучасних сортів України та сортів і селекційних ліній нашого інституту у порівнянні з такими в наборі сучасних сортів Західної Європи (переважно з Німеччини та Франції), що рекомендовані як високо врожайні для вирощування в Україні. За останні 2 роки 24 
оцінено фенотипи у 86 вітчизняних зразків, з яких лише у давнього сорту 'Одеська 16' виявлено сильний рівень фоточутливості, для решти зразків була притаманна слабка чутливість. А ось серед 37 сучасних іноземних сортів сильна фоточутливість була характерною для 22 з них!

Ще більш переконливими виявилися результати оцінок фоточутливості в наборі ліній $\mathrm{F}_{5}$, що отримані 3 гібридних комбінацій, у яких батьки розрізнялися за даними властивостями (матеріал люб'язно наданий Литвиненко М. А.). I як було наведено вище, з максимальною вірогідністю це були комбінації 3 моногенними відмінностями за алелями гена $P p d-D 1$. Вказані лінії були відібрані з поколінь, що розщеплюються, за ознакою вищої урожайності в умовах Одеси без будь-якої оцінки їхніх рівнів фоточутливості. Якщо припустити моногенні відмінності батьків за останньою ознакою, то при відсутності добору в даному поколінні очікується 46,875\% домінантних гомозигот, 6,25\% гетерозигот i $46,875 \%$ рецесивних гомозигот. Лише останні повинні виявляти сильну фоточутливість. Із оцінених нами 88 зразків таких було 40, і це високо достовірно підтверджує припущення, що добір за врожайністю не вплинув на зсув розщеплення за частотами рецесивних генів сильної фоточутливості, або інакше, сильно чутливі зразки виявилися не менш урожайними у порівнянні із слабко чутливими.

Тобто даний показник явно не лімітує рівень реальної урожайності гібридів в умовах Одеси. А висока частка саме таких генотипів серед багатьох іноземних рекомендованих для вирощування в Україні іноземних сортів не тільки підтримує такий висновок, але й підтверджує безперечну адаптивну цінність сильного рівня фоточутливості для певних реальних умов виробництва в нашій країні.

\section{Лiтература:}

1. Fjellheim S., Boden S., Trevaskis B. The role of seasonal flowering responses in adaptation of grasses to temperate climates. Frontiers in plant science. 2014. 29 Aug; 5:431. doi: 10.3389/fpls.2014.00431 
2. Kiss T., Balla K., Veisz O. [at all]. Allele frequencies in the $V R N-A 1, V R N-B 1$ and $V R N-D 1$ vernalization response and $P P D-B 1$ and $P P D-D 1$ photoperiod sensitivity genes, and their effects on heading in a diverse set of wheat cultivars (Triticum aestivum L.). Mol Breeding. 2014. Vol. 34, №2. P. 297-310. doi: 10.1007/s11032014-0034-2

3. Law C. N., Sutka J., Worland A. J. A genetic study of daylength response in wheat. Heredity. 1978. Vol. 41, №2. P. 185-191.

4. Scarth R., Law C.N. The location of the photoperiod gene $P p d 2$ and additional genetic factor for ear-emergence time on chromosome 2B of wheat. Heredity. 1983. Vol. 51, №3. P. 607-619.

5. Пірич А. В., Булавка Н. В., Юрченко Т. В. Фотоперіодична чутливість та яровизаційна потреба сортів пшениці м'якої озимої (Triticum aestivum L.) миронівської селекції. Зернові культури. 2018. Том 2, № 2. C. 261-266. doi: 10.31867/2523-4544/0034

6. Стельмах А. Ф., Литвиненко М. А., Файт В. І. Яровизаційна потреба та фоточутливість сучасних генотипів озимої м'якої пшениці. Збірник наукових пращь СГІ - НАЦ НАІС. Одеса, 2004. Вип. 5(45). С. 118-127.

7. Beales J., Turner A., Griffiths S. [та ін.]. A pseudo-response regulator is misexpressed in the photoperiod insensitive Ppd-Dla mutant of wheat (Triticum aestivum L.). Theor Appl Genet. 2007. Vol. 115. P. 721-733. doi:10.1007/s00122-007-0603-4

8. Chen F., Gao M., Zhang J. [та ін.]. Molecular characterization of vernalization and response genes in bread wheat from the Yellow and Huai Valley of China BMC Plant Biol. 2013. Vol. 13: 199. doi: 10.1186/1471-2229-13-199

9. Wilhelm E. P., Turner A. S., Laurie D. A. Photoperiod insensitive Ppd-Ala mutations in tetraploid wheat (Triticum durum Desf.). Theor Appl Genet. 2009. Vol. 118, №2. P 285-294. doi:10.1007/s00122-008-0898-9

10. Стельмах А. Ф., Файт В. И. Возможность улучшения адаптивности озимой пшеницы путем усиления фотопериодизма и потребности в яровизации. Збірник наукових пращь СГІ-НЦНС. Одеса, 2016. Вип. 27. С. 103-108. 